Z Badań nad Książką i Księgozbiorami Historycznymi 2019. T. specjalny: Dla Niepodległej The Studies into the History of the Book and Book Collections 2019. Special issue: For an Independent Poland

Henryka Ilgiewicz

https://doi.org/10.33077/uw.25448730.zbkh.2020.194

Lithuanian Culture Research Institute in Vilnius

Ilgiewicz@mail.ru

ORCID 0000-0002-4504-5638

\title{
Friends of Vilnius libraries in the interwar period
}

\begin{abstract}
In the interwar period, there were several Polish Societies in Vilnius, e.g. the Society of Friends of The Stefan Batory University Library (1924-1939), The Eustachy and Emilia Wróblewski Scientific Society (1922-1939), The Society of Friends of the Eustachy and Emilia Wróblewski State Library (1936-1939), The Tomasz Zan Circle of Libraries of the Polish School Organization (1919-1939), whose purpose was to support the libraries of Vilnius. They were interested in all matters related to libraries and tried to engage city officials and society at large in these matters. They also collected gifts (books, manuscripts, etc.) and cash funds for library needs. They organized readings, concerts, and other projects to raise funds for the libraries. The activities of these societies significantly influenced the development of some libraries in Vilnius.
\end{abstract}

Key words: Society of Friends of the Stefan Batory University Library - The Eustachy and Emilia Wróblewski Scientific Society - The Society of Friends of the Eustachy and Emilia Wróblewski State Library - The Library Circle of the Tomasz Zan Society of the Polish School Organization.

„Z Badań nad Książką i Księgozbiorami Historycznymi” - Udział zagranicznych recenzentów w ocenie publikacji; Stworzenie anglojęzycznej wersji wydawniczej publikacji; Digitalizacja tomów archiwalnych rocznika w celu zapewnienia otwartego dostępu do nich przez Internet oraz wdrożenie i utrzymanie cyfrowej platformy redakcyjnej - zadanie finansowane w ramach umowy $\mathrm{nr}$ 653/P-DUN/2019 ze środków Ministra Nauki i Szkolnictwa Wyższego przeznaczonych na działalność upowszechniającą naukę. 
In the interwar period, there were several Polish Societies in Vilnius, e.g. The Tomasz Zan Circle of Libraries of the Polish School Organization (1919-1939), The Society of Friends of The Stefan Batory University Library (1924-1939), The Eustachy and Emilia Wróblewski Scientific Society (1922-1939), The Society of Friends of the Eustachy and Emilia Wróblewski State Library (1936-1939). They were interested in libraries matters themselves, as well as they tried to raise the interest of municipal authorities and communities, they gathered donations (books, manuscripts) and funds for libraries' needs, organized lectures, concerts, and other events. The activity of the aforementioned associations contributed significantly to the development of Vilnius libraries.

\section{The Tomasz Zan Circle of Libraries of the Polish School Organization (1919-1939)}

The Tomasz Zan Circle of Libraries of the Polish School Organization in the Eastern Territories (PSO) was established in November 1919, initiated by the Organisation's Vice President priest Stanisław Miłkowski, who became the Circle's President. The Management Board included: Zofia Kiewliczowa, Ludwika Ruszczycówna, Stefania Montwiłłowa, Władysław Bodziachowski, Maria Reutt, and Wanda Wojewódzka. First, the Circle established a small reading room for promotion of reading in Polish, on the PSO Central Management premises at Benedyktyńska 2 str., managed by W. Bodziachowski. However, the reading room stopped its activity after several months due to inadequate conditions, and its book collection was taken over by the PSO Central Management lending services ${ }^{1}$.

The idea of reading room was revived after fighting off the second Bolshevik battalion, and liberation of Vilnius by the Polish troops under gen. Lucjan Żeligowski's command in October 1920. Despite hard circumstances in the town demolished by war and occupation, the premises were obtained thanks to S. Miłkowski mediation (five rooms and one large auditorium), in the building at St. Anna 7 str. (currently: Maironio str.). Material support was provided by the PSO Central Management, and an appeal to the public issued. The latter informed that the PSO Circle of Libraries in Vilnius opened a reading room of journals and scientific books, aiming at "offering people of all conditions and professions a possibility not only to read newspapers, but also to train their own minds". The appeal also included a request to institutions and individuals to donate or lend tables, shelves, cupboards,

1 L. Ruszczycówna, Biblioteka im. Tomasza Zana, [in:] Biblioteki wileńskie, ed. by A. Łysakowski, Wilno 1932, p. 165. 
chairs, but first of all books and handbooks of all scientific domains, as well as works of renowned authors ${ }^{2}$.

Thanks to the initiators efforts and generosity of the society, the reading room named "Self-education" had been organized within a month, and formally opened on December 21, 1920. The service for the souls of Tomasz Zan and all the Filarets was conducted in the St Michael church that day in the morning, in the presence of the Circle's members, professors of the Stefan Batory University (hereafter: USB), representatives of academic and school youth. In the evening, after the consecration of the premises and speeches, participants of this celebration went to the auditorium where Marian Massionius, the USB professor, gave a lecture concerning Tomasz Zan, a Filaret and Polish poet ${ }^{3}$.

The newly open reading room managed by L. Ruszczycówna began its activity with the collection of 158 books and a few journal titles ${ }^{4}$. Its further development depended mostly on social support. Therefore the PSO Central Management appealed again to the society for financial donations, "which will be spent for Polish books, as effective as lead bullets in fighting against the enemy"s.

The facility had been developing fast, thanks to the support of the public and the Department of Education of the Republic of Central Lithuania. It consisted of 2524 works and 30 journal titles in total in 1922 and had quite a large group of users (1686 in February 1922). They were mostly students of schools of different types, as well as former soldiers who (after peace treaty) wanted to finish education broken by the war with Soviet Russia. Popular lectures concerning nature, technology, sightseeing, history, and religious studies were also organized in the reading room, as well as meetings for children, with slideshows ${ }^{6}$.

The facility named the Tomasz Zan Library in 1923 was moved to a larger premises at Wielka Pohulanka 14/15 str. (currently: Jono Basanavičiaus) in 1925. The library staff included: L. Ruszczycówna as a chief and three employees: Maria Zdrojewska, Helena Kadenacówna and Jadwiga Chrzanowska. Funds for the maintenance of the library from the PSO Central Management and the users payments were insufficient. The Circle's Management had to apply

\footnotetext{
2 Odezwa Polskiej Macierzy Szkolnej, “Gazeta Wileńska” 14.11.1920, no 19, p. 4.

3 Nabożeństwo za duszę ś. p. Tomasza Zana, "Gazeta Wileńska" 19.12.1920, no 48, p. 3; Otwarcie czytelni "Samoksztatcenie", ibidem, 19.12.1920, no 48, p. 3; Czytelnia "Samoksztatcenie" Koła Bibliotecznego im. Tomasza Zana PMSz, ul. Św. Anny 7, ibidem, 24.12.1920, no 52, p. 7; Podziękowanie [Zarządu Koła Bibliotecznego im. Tomasza Zana Polskiej Macierzy Szkolnej], ibidem, 24.12.1920, no 52, p. 7; Nowa placówka, ibidem, 28.12.1920, no 53, p. 3.

4 L. Ruszczycówna, Biblioteka im. Tomasza Zana..., p. 166.

5 Polska Macierz Szkolna do społeczeństwa polskiego, "Gazeta Wileńska” 23.12.1920, no 51, p. 3.

6 Działalność Koła Bibliotecznego im. Tomasza Zana, "Oświata Pozaszkolna” 1922, vol. 2, no 6, pp. 407-408.
} 
for subsidies from state and local budgets year by year. It was also supported by the Ministry of Religious Affairs and Public Education, the Vilnius Municipality (permanent subsidy of 5 thousand PLN yearly), occasionally Presidium of the Council of Ministers, Department of Work and Social Care in Vilnius, regional assemblies of Vilnius-Troki, Święciany and Mołodeczno. State and local government grants have become particularly important during the global economic crisis when public generosity decreased. For example, the library's budget amounted to 23917 PLN in the reference year 1930-1931, including 8670 PLN from state grants, 9950 PLN - from local government subsidies, and no more than 792,5 PLN from donations and membership fees. The other funds came from readers' payments (3086,95 PLN) and other sources ${ }^{7}$.

The library's collections had been systematically increasing despite financial difficulties. It consisted of 9761 works in 11247 volumes as of March 31, 1930. In the reference year 1929-1930, there were 3542 readers in the library, including 1596 secondary school students, 603 from vocational schools, 364 from teachers seminars, 355 university students, 268 students from other schools and 356 adults $^{8}$. On April 1, 1932, the book collection amounted to 10574 works in 12144 volumes, almost half of them were donated. The library had 3641 readers, mostly young people in their education process ${ }^{9}$.

The library's management and staff planned to develop their premises, to organize lending services (the collection was available on site only, in reading rooms), to organize children section, to complete the collection with titles in foreign languages, classic literature in particular. However, the global economic crisis deepening since 1929 stood in the way of implementing these plans. The Tomasz Zan Circle of Libraries and its Library also found itself in a difficult situation. The library's management, together with many people interested in maintaining this facility, important for Polish education and culture, decided to make it independent and to establish a new organization - the Tomasz Zan Association for Self-Education (Towarzystwo Pomocy w Samokształceniu im. Tomasza Zana) - to assure funding for the library and its existence, as well as to support its further activities ${ }^{10}$.

When the new association was approved, the T. Zan Library was taken over, however, it did not break its relations with the Polish Schools Organisation. Part of its collection, which was developed while the library belonged to the PSO Circle of Libraries, stayed within as a perpetual deposit of PSO.

\footnotetext{
L. Ruszczycówna, Biblioteka im. Tomasza Zana ..., pp. 166-168.

8 H. Radlińska, Biblioteka i czytelnia im. Tomasza Zana w Wilnie, "Oświata i Wychowanie" 1930, vol. 2, no 8, pp. 789-791.

9 L. Ruszczycówna, Biblioteka im. Tomasza Zana ..., pp. 169-172.

10 L. Ruszczycówna, Biblioteka im. Tomasza Zana..., p. 173; Statut Towarzystwa Pomocy w Samoksztatceniu imienia Tomasza Zana, Wilno 1932.
} 
New acquisitions since April 1932 were property of the Tomasz Zan Association for Self-Education ${ }^{11}$.

The Tomasz Zan Library received a new building designed by Jan Borowski ${ }^{12}$ to its use in 1936, at the foot of Bauffałowa Hill (currently: Tauro, Eng. Tauras Hill), at the corner of Jakub Iasiński, Zygmunt Sierakowski and Piekiełko streets (the building has not survived until current days). The cost of the building amounted to 35 thousand PLN ${ }^{13}$.

The opening ceremony and consecration of the new premises took place on Sunday, November 1, 1936, attended by A. Prystor, Ludwik Bociański, the Vilnius voivode, Kazimierz Gintowt-Dziewałtowski, the deputy voivode, and Marian Godecki, inspector of the Vilnius school district. Archbishop Romuald Jałbrzykowski consecrated the building, and gave a short speech, comparing education works to a sunray in a grey weekday. Next S. Miłkowski recalled the history of the library and thanked all the donators and friends who had been supporting it. The guests speaking after him (K. Godecki, Witold Węsławski - the PSO President, Adam Łysakowski - director of the University Library) emphasized the role of this library in the Vilnius cultural life ${ }^{14}$.

A cloakroom, a cataloguing room, a magazine, the Self-Education Advisory of the Polish Librarians Union, a chancellery, a janitor's flat, and toilets were located at the ground floor of the new building, and four reading rooms at the first floor. The library's collection consisted of 16681 volumes on September 1, 1937. They were divided into six sections: 1. Main collection; 2. Youth collection; 3. Periodicals; 4. Cartography, 5. Music notes; 6. Albums and drawings. Each of these sections had its individual inventory and catalogues. Readers frequency was significant. For instance, there were 23588 visits in the reference year 1936/1937, including - 11869 of the youth up to 18, and 11729 of the young adults $18+$. The library's addmission was : 0,1 PLN daily, 1 PLN monthly. School youth paid half of this rate ${ }^{15}$.

Moreover, the Tomasz Zan Association for Self-Education took over the library at Adam Mickiewicz 28 str. (currently: Gedimino) in 1932, donated by Elżbieta and Antonina Żukowski. The donors set a condition that until they

11 A. Siedlaczek-Szwed, Towarzystwo Polskiej Macierzy Szkolnej Ziemi Wileńskiej w Drugiej Rzeczypospolitej, "Prace Naukowe Akademii im. Jana Długosza w Częstochowie. Seria Pedagogika" 2008, vol. 17, p. 196.

12 Borowski Jan, ur. 1890, zm. 1966; architekt, pedagog, [in:] Encyklopedia Ziemi Wileńskiej: Architektura, dzieła i twórcy od XVI w. do 1945 r., compiled by M. Jackiewicz, Bydgoszcz 2006, pp. 16-17.

13 H. Romer [Romer-Ochenkowska Helena], Biblioteka i czytelnia im. T. Zana w nowym lokalu, "Kurier Wileński”" 25.10.1936, no 293 (3896), p. 9.

14 M. W., Otwarcie Biblioteki im. Tomasza Zana, "Kurier Wileński" 02.11.1936, no 301 (3904), p. 2.

15 [Walerian Charkiewicz] W.Ch, Biblioteka im. Tomasza Zana w Wilnie, "Słowo" 25.11.1937, no 327 (4891), p. 5. 
could they would manage the library themselves free of charge. The lending service offered 12006 works in 1937. Both libraries (Tomasz Zan Library and the lending service) exchanged publications ${ }^{16}$.

\section{The Society of Friends of The Stefan Batory University Library}

The Society of Friends of The Stefan Batory University Library in Vilnius (renamed officially as the Society of Friends of the University Public Library in Vilnius ${ }^{17}$ in 1925) was established in 1924, initiated by the USB rector Prof. Alfons Parczewski. His article was published in the Vilnius daily "Słowo" (Word) of April 3, 1924, where he wrote that the university library in Vilnius was scientifically the poorest in Poland due to the Russian occupation, therefore "there is clearly an urgent need of establishment of the society of friends of the university library in Vilnius, reminiscent of the one already established in Kraków"18.

The Vilnius inhabitants answered A. Parczewski's appeal. The founding meeting of the Society of Friends of The Stefan Batory University Library in Vilnius took place on April 12, 1924, in the USB Senate hall, attended by approx. 50 persons ( 100 were invited). The meeting was opened by Prof. A. Parczewski, who thanked the attendees for coming and presented the associations' aims and tasks. Then spoke: Stefan Rygiel Ph.D., director of the University Library, Wacław Studnicki (Gizbert-Studnicki), an archivist, Witold Węsławski Ph.D., Prof. Kazimierz Błażewicz, and others. All of them spoke in favor of establishing the association. When the speeches were finished, an executive committee was established, including Prof. A. Parczewski, S. Rygiel, Prof. Czesław Falkowski, a priest, Prof. Franciszek Bossowski, Konstanty Bukowski, and Piotr Hniedziewicz. Henryk Krygier, director of the Vilnius branch of the Gebethner \& Wolf bookstore, initiated a collection for the newly established organization at the end of the meeting. More than one billion Polish marks ${ }^{19}$ were collected and

16 Ibidem, p. 5.

17 Vilniaus universiteto biblioteka, Rankraščių skyrius, (Pol. Biblioteka Uniwersytetu Wileńskiego, Dział Rękopisów, Eng. The Vilnius University Library, Department of Manuscripts; abbreviation: VUB, RS), sign. F 47-716, p. 13, Protokół III posiedzenia Zarządu Towarzystwa Przyjaciół Biblioteki Uniwersytetu Stefana Batorego w Wilnie dn. 9 lutego 1925 r.

18 A. Parczewski, O pomoc dla Biblioteki Uniwersytetu $w$ Wilnie, "Słowo" 3.04.1924, no 77 (494), p. 2.

19 Four currencies were in circulation at the territory of the $2^{\text {nd }}$ Republic of Poland just after independence regain in November 1918: German mark, Austrian crown, tsarist rouble, and Polish mark (currency of Kingdom of Poland). The Polish Parliament set the Polish mark as the only currency of the Polish state in January 1920. Due to instable situation of the Treasury during the Polish-Bolshevik war and just after it the Polish mark was subject ot inflation. A moderate inflation of a mark turned into a hyperinflation in 1923, which led to a serious crisis of the State Treasury, the collapse of Wincenty Witos cabinet, and establishment of Władysław Grabski government in December 1923. 
given to S. Rygiel. The most generous donors were: Tobiasz Bunimowicz (half billion Polish marks, Zygmunt Nagrodzki, Arseniusz Pimonow, Prof. Kazimierz Błażewicz (50 million Polish marks each) ${ }^{20}$.

The association was seated in Vilnius, in the Vilnius University Library (other names: the USB Library in Vilnius, the Public and University Library in Vilnius). The city of Vilnius and the Vilnius Region were the area of its activity $^{21}$. Its statute defined four membership categories: ordinary members, supporting, life and honorary members. Ordinary members paid an annual fee of 24 PLN, supporting - 60 PLN. A private or legal entity who donated once no less than 300 PLN could become a life member, and the individual particularly contributed to the association or library - an honorary member ${ }^{22}$. For instance, A. Parczewski was unanimously elected an honorary member at the general meeting in $1926^{23}$. According to information in the "Nauka Polska" (Polish Science) journal in 1926, the association had 150 members. Unfortunately, a list of members was not created or it has not survived until now ${ }^{24}$.

The members elected 6 Management Board members and three to a Review Commission from among themselves at a general meeting. Moreover, the USB rector and a director of the University Library joined the Management Board ex officio ${ }^{25}$. The first meeting of the Management Board chaired by A. Parczewski took place on July 7, 1924. The Board was selected by voting as follows: President - count Marian Bröel-Plater, a bibliophile, Vice President - Stanisław Kościałkowski, treasurer - Jan Klott, secretary

The government established a new currency - Polish zloty - and its issuer - the Bank of Poland. See: [online] https://pl.wikipedia.org/wiki/Reforma_walutowa_W\%C5\%82adys\%C5\%82awa_Grabskiego [retrieved at 24.10.2018].

20 K.B., Towarzystwo Przyjaciół Biblioteki Uniwersyteckiej w Wilnie, "Słowo" 15.04.1924, no 87 (504), p. 2; S. Rygiel, Wilno swej bibliotece, "Słowo" 19/20.04.1924, no 90 (507), p. 3.

21 VUB, RS, sign. F 47-922/1, p. 1, § 2, Statut Towarzystwa Przyjaciół Biblioteki Uniwersytetu Stefana Batorego w Wilnie; Lietuvos centrinis valstybès archyvas (Państwowe Archiwum Centralne Litwy, Eng. Lithuanian Central State Archives; abbreviation: LCVA), sign. F 53, ap. 23, b. 2516, p. 1 , Arkusz ewidencyjny Towarzystwa Przyjaciół Biblioteki USB w Wilnie.

22 VUB, RS, sign. F 47-922/1, pp. 1-25, § 7-16, Statut Towarzystwa Przyjaciół Biblioteki Uniwersytetu Stefana Batorego w Wilnie; Lietuvos mokslų akademijos Vrublevskių biblioteka, Rankraščiu skyrius (Biblioteka im. Wróblewskich Litewskiej Akademii Nauk, Dział Rękopisów, Eng. The Wróblewski Library of the Lithuanian Academy of Sciences, Department of Manuscripts, LMAVB, RS), sign. F 75-711, p. 52, § 7-16, Statut Towarzystwa Przyjaciół Biblioteki Uniwersytetu Stefana Batorego w Wilnie.

23 VUB, RS, sign. F 47-716, pp. 17-23, Protokół Walnego Zebrania Towarzystwa Przyjaciół Biblioteki Publicznej Uniwersyteckiej, odbytego w lokalu Biblioteki Publicznej Uniwersyteckiej 6. III. $1926 \mathrm{r}$.

24 Towarzystwo Przyjaciót Biblioteki Publicznej i Uniwersyteckiej w Wilnie (Uniwersytecka 5, Biblioteka), "Nauka Polska" 1927, vol. 7, p. 424.

25 VUB, RS, sign. F 47-922/1, p. 2-3, § 24, 29, Statut Towarzystwa Przyjaciół Biblioteki Uniwersytetu Stefana Batorego w Wilnie; LMAVB, RS, sign. F 75-711, p. 54, § 24, 29, Statut Towarzystwa Przyjaciół Biblioteki Uniwersytetu Stefana Batorego w Wilnie. 
- P. Hniedziewicz, members - W. Węsławski, Z. Nagrodzki, Parczewski, S. Rygiel $^{26}$. Monsignor Adam Sawicki ${ }^{27}$ was elected to the board replacing outgoing W. Węsławski at the meeting on March 6, 1926. The Review Commission consisted of Stanisław Rzewuski, Tadeusz Rostworowski, A. Sawicki ${ }^{28}$ at the beginning of the association's activity.

The organization's fund was collected from membership fees, donations, interests from bank savings, and the association's activity ${ }^{29}$. The association received 242,43 PLN and 60 USD in 1924, 271,48 PLN and 60 USD in 1925, 793,96 PLN in 1926, 844,91 PLN and 18 USD in 1927, and 566,31 PLN in 1928. Expenditures in 1925 amounted to 133,48 PLN, 612,71 PLN and 45 USD in 1926, 360,60 PLN in 1927, and 515 PLN in $1928^{30}$. Moreover, more than 1 billion Polish marks were collected in voluntary fees during organization meeting, which exchanged into PLN were also spent on the needs of the University Library. The association could spend 1000 PLN in total for the purchase of machines for the library bookbindery, and 500 PLN for the purchase of books in total ${ }^{31}$.

The association members had been also donating many books from their private libraries, and encouraging the owners of valuable book collections to do so. Membership fees in kind were accepted in particular cases, i.e. books, manuscripts, etc. ${ }^{32}$ Some of donated books not needed in the library were sold during public auctions, and collected funds were spent on the library's activity ${ }^{33}$.

The association's activity broke during the global economic crisis. A lot of members withdrew (there were 18 members in 1929 and 17 in 1930), the Management Board and the Review Commission had been working without full membership, board and general meetings were not organized. Only 51,31 PLN was at the association's account in the years 1929-1930, because

26 VUB, RS, sign. F 47-716, p. 10, Protokół I posiedzenia Zarządu dn. 7 lipca 1924 r.

27 VUB, RS, sign. F 47-716, pp. 17-23, Protokół Walnego Zebrania Towarzystwa Przyjaciół Biblioteki Publicznej Uniwersyteckiej, odbytego w lokalu Biblioteki Publicznej Uniwersyteckiej 6 III $1926 \mathrm{r}$.

28 VUB, RS, sign. F 47-716, wklejka na drugiej stronie okładki Księgi protokołów, Skład Zarządu Towarzystwa Przyjaciół Biblioteki Publicznej Uniwersyteckiej.

29 VUB, RS, sign. F 47-922/1, § 17-18, Statut Towarzystwa Przyjaciół Biblioteki Uniwersytetu Stefana Batorego w Wilnie.

30 VUB, RS, sign. F 47-717/1, p. 1-7, Książka rachunkowa Towarzystwa Przyjaciół Biblioteki Publicznej i USB w Wilnie.

31 VUB, RS, sign. F 47-716, p. 10, Protokół I posiedzenia Zarządu dn. 7 lipca 1924 r.; Towarzystwo Przyjaciół Biblioteki Uniwersytetu Stefana Batorego w Wilnie, "Nauka Polska" 1927, t. 6, p. 364 , vol. 7 , p. 424.

32 VUB, RS, sign. F 47-716, p. 11, Protokół II zwyczajnego posiedzenia Zarządu Towarzystwa Przyjaciół Biblioteki Uniwersytetu Stefana Batorego w dniu 11 VIII 1924 r.

33 VUB, RS, sign. F 47-716, p. 13, Protokół III posiedzenia Zarządu Towarzystwa Przyjaciół Biblioteki Uniwersytetu Stefana Batorego w Wilnie dn. 9 lutego1925. 
the collection of membership fees went very slowly ${ }^{34}$. The Vilnius District Office (starostwo grodzkie), worried about this state of affairs, sent a letter to the Management Board of the Society of Friends of The Stefan Batory University Library in Vilnius on May 5, 1931, calling it to inform the local government office about the status of the organization ${ }^{35}$.

After receiving this letter the members called a general meeting on May 11, 1931. Participants heard and took note of the report from the Management Board's activity, presented by President M. Bröel-Plater, and the financial report presented by the treasurer J. Klott. Then a discussion took place, concerning the future of the association; the following spoke: M. Bröel-Plater, J. Klott, prof. Aleksander Januszkiewicz, A. Łysakowski, H. Krygier. After hearing the opinions, the participants decided to continue the association's activity, they elected a new Management Board and new Review Commission. The board consisted of: M. Bröel-Plater - President, prof. F. Bossowski - Vice President, J. Klott - treasurer, Mikołaj Dzikowski, a librarian - secretary, S. Kościałkowski and A. Sawicki - board members. A. Januszkiewicz, the USB rector, and A. Łysakowski, director of the University Library, joined the management board ex officio. The following were elected to the Review Commission: Stanisław Białaś, T. Bunimowicz, and H. Krygier. As many members were in arrears, it was decided to spread overdue fees in such a way that besides current fee members would pay monthly 1 PLN to settle arrears due ${ }^{36}$.

The most important task of the new board was to make contacts with former members and reach new ones, as well as to collect overdue fees which were the main income source for the association. The Board published press information about the organization, its goals and tasks, to awake interest of the Vilnius society in its activity. It also appealed to the intelligentsia to join the friends of the University Library ${ }^{37}$. As a result of these efforts 420 PLN was received from the membership fees in 1931, 100 PLN included from director T. Bunimowicz. Another 149 PLN were received until April 19, 1932. The association's income in total amounted to 620,31 PLN in the reference year 1931/1932. During the

34 VUB, RS, sign. F 47-717/1, pp. 8-9, Książka rachunkowa Towarzystwa Przyjaciół Biblioteki Publicznej i USB w Wilnie.

35 LCVA, sign. F 53, ap. 23, b. 2516, p. 4, Starostwo Grodzkie Wileńskie do Zarządu Towarzystwa Przyjaciół Biblioteki USB w Wilnie, Wilno, 5.V.1931.

36 VUB, RS, sign. F 47-716, pp. 33-34, Protokół walnego zebrania członków Towarzystwa Przyjaciół Uniwersyteckiej Biblioteki Publicznej w Wilnie, odbytego dnia 11 maja 1931 r. w gmachu Uniwersyteckiej Biblioteki Publicznej; LCVA, sign. F 53, ap. 23, b. 2516, p. 18, Towarzystwo Przyjaciół Biblioteki Uniwersytetu Stefana Batorego w Wilnie do Pana Starosty Grodzkiego w Wilnie, 15.V.1931 r.; Kronika: Zarząd Towarzystwa Przyjaciót Uniwersyteckiej Biblioteki Publicznej w Wilnie, "Słowo" 25.04.1931, no 94 (2602), p. 3.

37 Towarzystwo Przyjaciól Uniwersyteckiej Biblioteki Publicznej w Wilnie, "Kurier Wileński" 25.04.1931, no 94 (2036), p. 3; T-wo Przyjaciół Uniw. Biblioteki Publicznej w Wilnie, "Słowo" 25.04.1931, no 94 (2602), p. 3. 
board meeting on April 19, 1932, at M. Bröel-Plater request, it was decided to transfer 600 PLN from the above-mentioned sum to the University Library, for book acquisition. It was also decided to ask the Ministry of Religious Affairs and Public Education for increased subsidy for book acquisition and other needs of the University Library ${ }^{38}$.

Due to the protracted economic crisis, the association again found itself in a difficult situation in the following years. However, despite high obstacles, it continued its activity. The general meeting was called on May 27, 1935. M. Bröel-Plater opened, asking the participants to mark their respect for the memory of Marshal Józef Piłsudski, a reviver and protector of the Vilnius University. They stood in a moment of silence for the late commander. Then the President informed about the losses suffered by the association: deaths of a longterm treasurer J. Klott and members of the Review Commission S. Białas and H. Krygier, as well as the honorary member A. Parczewski (who died on April 21, 1933). Upon President's request, the participants stood in a moment of silence to honour their memory.

The need for new members was also discussed there, as there were only 12 left in the association (M. Bröel-Plater, F. Bossowski, T. Bunimowicz, M. Dzikowski, Helena Hleb-Koszańska, A. Januszkiewicz, S. Kościałkowski, Maria Kotwiczówna, A. Łysakowski, A. Sawicki, Kazimierz Świątecki, Lucjan Uziębło). Participants decided to decrease an annual fee to 6 PLN, to maintain current and reach new members. The new Management Board and Review Commission were also elected there. The Board included: President M. Bröel-Plater, Vice President F. Bossowski, secretary H. Hleb-Koszańska, treasurer M. Kotwiczówna, members: S. Kościałkowski, A. Sawicki, ex officio: Witold Staniewicz, the USB rector and A. Łysakowski, director of the University Library. M. Dzikowski, T. Bunimowicz and K. Świątecki were elected to the Review Commission ${ }^{39}$.

As in previous years, the Management Board tried to reach new members and thus the association. For this purpose short messages were broadcasted in the radio, an extract from the statute and a letter promoting the idea of the society and encouraging to join it, were sent to various organizations, editorial offices

38 LCVA, sign. F 53, ap. 23, b. 2516, p. 8, Protokół III posiedzenia Zarządu Przyjaciół Uniwersyteckiej Biblioteki Publicznej w Wilnie w dniu 19 kwietnia 1932 r.; VUB, RS, sign. F 47-716, k. 10-11, Książka rachunkowa Towarzystwa Przyjaciół Biblioteki Publicznej i USB w Wilnie.

39 VUB, RS, sign. F 47-716, pp. 36-37, Protokół walnego zebrania członków Towarzystwa Przyjaciół Uniwersyteckiej Biblioteki Publicznej w Wilnie, odbytego dnia 27 maja 1935 r. w gmachu Uniwersyteckiej Biblioteki Publicznej; VUB, RS, sign. F 47-716, p. 37, Protokół V (XVI) posiedzenia Zarządu Towarzystwa Przyjaciół Biblioteki Uniwersyteckiej w Wilnie w dn. 27 maja 1935 r.; LCVA, sign. F 53, ap. 23, b. 2516, p. 3, Towarzystwo Przyjaciół Biblioteki Uniwersytetu Stefana Batorego w Wilnie do Pana Starosty Grodzkiego w Wilnie, Wilno, 23 kwietnia 1936 r. 
of daily papers, and individuals ${ }^{40}$. However, the group of members increased insignificantly. The association was joined by Edward Hofman Ph.D., a pensioner, Jadwiga Mozołowska, a secondary school teacher, Witold Rudziński, a musician in 1936. In 1938 - Sergiusz Arseniew and Stanisław Lisowski, the librarians, Henryk Rzędowski, retired school inspector, Henryk Teitelbaum, a lawyer, Wacława Walicka, a pensioner, and Napoleon Baniewicz, a medical doctor ${ }^{41}$.

Due to a small number of members and decreased fees, the association did not have significant amounts that could have been spent on the library's needs. Its budget amounted in 1936 to 202,11 PLN, in 1937 - 159,86 PLN, in $1938-188,31$ PLN. There was 197,31 PLN at the association's account in April 1939. Larger expenditures were made in 1936, when 154,85 PLN were given to the University Library for the needs of the "Marshal Piłsudski and Vilnius" exhibition ${ }^{42}$. A lot of attention was given to acquiring donors outside the association at the same time. "Kurier Wileński" (Vilnius Courier) daily informed that approximately 11000 volumes were received by the University Library in the reference year $1935 / 1936,60 \%$ of the acquisition came from a legal deposit, $18 \%$ from donations, $15 \%$ from exchange, and $8 \%$ from purchase. The most generous donation (more than 51 thousand PLN) came from the Military Family for Commemoration of Marshal Józef Piłsudski (Rodzina Wojskowa ku Uczczeniu Marszałka Józefa Piłsudskiego). Besides that, the library received the book collection from the legacy of Stanisław Władyczka as a donation and taken over the book collection of the Vilnius Medical Association as a permanent deposit ${ }^{43}$.

The University Library collections increased thanks to the support of the Polish government, the society's generosity, and the efforts of its employees.

40 VUB, RS, sign. F 47-712/1, p. 27, Sprawozdanie Zarządu Towarzystwa Przyjaciół Biblioteki Uniwersyteckiej w Wilnie za czas od 27.V.1935 do 26.VI. 1936.

41 VUB, RS, sign. F 47-712/1, Spis członków Towarzystwa Przyjaciół Biblioteki Uniwersyteckiej w Wilnie, 1936; VUB, RS, sign. F 47-712/1, p. 12, Deklaracja [Witolda Rudzińskiego] do Zarządu Towarzystwa Przyjaciół Biblioteki Uniwersyteckiej w Wilnie, dn. 16 lipca 1936 r.; ibidem, p. 13, Deklaracja [Sergiusza Arsenjewa] do Zarządu Towarzystwa Przyjaciół Biblioteki Uniwersyteckiej w Wilnie, dn. 15.III.1936 r.; ibidem, p. 15, Deklaracja [Stanisława Lisowskiego] do Zarządu Towarzystwa Przyjaciół Biblioteki Uniwersyteckiej w Wilnie, 15 marca 1938 r.; ibidem, p. 16, Deklaracja [Henryka Rzędowskiego] do Zarządu Towarzystwa Przyjaciół Biblioteki Uniwersyteckiej w Wilnie, 1 marca 1938 r.; ibidem, p. 17, Deklaracja [Henryka Teitelbauma] do Zarządu Towarzystwa Przyjaciół Biblioteki Uniwersyteckiej w Wilnie, 7 kwietnia 1938 r.; ibidem, p. 18, Deklaracja [Wacławy Walickiej] do Zarządu Towarzystwa Przyjaciół Biblioteki Uniwersyteckiej w Wilnie, 15 marca 1938 r.; ibidem, p. 19, Deklaracja [Napoleona Baniewicza] do Zarządu Towarzystwa Przyjaciół Biblioteki Uniwersyteckiej w Wilnie.

42 VUB, RS, sign. F 47-717/1, pp. 13-18, Książka rachunkowa Towarzystwa Przyjaciół Biblioteki Publicznej i USB w Wilnie; VUB, RS, sign. F 47-716, pp. 37-38, Protokół VI (XVIII) posiedzenia Zarządu Towarzystwa Przyjaciół Biblioteki Publicznej i USB w Wilnie, odbytego w dn. 18.V.1936 r. w gmachu Biblioteki Uniwersyteckiej o godz. 18.30.

43 Biblioteka Uniwersytecka w Wilnie w roku 1935/36, "Kurier Wileński” 23.10.1936, no 291 (3894), p. 7. 
On a day before the World War II it amounted to 411928 volumes of printings from the $17^{\text {th }}$ century or newer, 254 incunabula, 2503 volumes of printings from the $16^{\text {th }}$ century, 13399 manuscripts, 10853 units of cartography, 6680 units of iconography, 1817 units of musical notes, 114 museum objects, 150442 units of exchangeable reserve, and numerous ephemera. The Society of Friends of The Stefan Batory University Library in Vilnius also contributed to the development of this collection ${ }^{44}$.

\section{The societies supporting the Eustachy and Emilia Wróblewski State Library in Vilnius}

The Eustachy and Emilia Wróblewski State Library in Vilnius, which was established under the agreement on February 1, 1926, between the Committee of the Eustachy and Emilia Wróblewski Scientific Society and the Ministry of Religious Affairs and Public Education, also benefited from public support ${ }^{45}$. The Society, executing the will of its founder, a Vilnius barrister and bibliophile Tadeusz Wróblewski, contributed significantly to the library's establishment and did not cease to supervise its further development. Many valuable printings, manuscripts, drawings and museum objects were purchased by the Committee's efforts and a book series concerning the history and multinational culture of the territories of the former Great Duchy of Lithuania was published. These publications donated to the library, and exchanged into publications of other institutions, contributed to enrich the collection with new acquisitions. The great collection of Ludwik Abramowicz was purchased by the Society (6200 PLN) in 1930, consisting of 220 objects (pictures, drawings, portraits of people associated with Vilnius). Joined with the objects from the T. Wróblewski collection, and completed with new acquisitions, it became a foundation for the museum section, commonly known as the Iconographic Museum of Vilnius (Muzeum Ikonograficzne Wilna) at the Wróblewski State Library $^{46}$. Initially, the library's management located museum collection in two rooms, and the Committee offered funds for its equipment. Ludwik Abramowicz, Vice President of the Eustachy and Emilia Wróblewski Scientific Society,

44 Biblioteki na wschodnich ziemiach II Rzeczypospolitej: Informator, ed. by B. Bieńkowska, compiled by U. Paszkiewicz et al., Poznań 1998, pp. 628-629.

45 LMAVB, RS, sign. F 75-22/2, pp. 106-109, Umowa podpisana pomiędzy Stefanem Dembym, działającym w imieniu Ministerstwa Wyznań Religijnych i Oświecenia Publicznego na mocy zlecenia Ministra WR i OP Pana Stanisława Grabskiego a Komitetem Towarzystwa Pomocy Naukowej im. Eustachego i Emilii Wróblewskich, istniejącego na mocy Statutu, zatwierdzonego przez Delegata Rządu dla Ziemi Wileńskiej w dn. 19-ym sierpnia 1922 roku, Wilno, dn. 1 lutego 1926 r.

46 LMAVB, RS, sign. F 75-8, p. 46, Protokół nr 6 zebrania Komitetu Towarzystwa Pomocy Naukowej im Eustachego i Emilii Wróblewskich w dniu 12 czerwca 1930 r; LMAVB, RS, sign. F 75 11/4, pp. 282-288, Sprawozdanie z działalności Biblioteki Państwowej im. Wróblewskich w Wilnie za $1930 \mathrm{r}$ 
supervised organisation of the exhibition, and became an honorary curator of the museum collection of the Wróblewski State Library. The Iconographic Museum of Vilnius was basically organized in December $1931^{47}$.

The Society assigned funds from the sale of an unfinished building at Słowackiego street (100 000 PLN) to the Ministry of Religious Affairs and Public Education, and interests from the funds in the Central Fund of Farming Companies in Vilnius (Centralna Kasa Spółek Rolniczych w Wilnie) for purchase of books, journals and museum objects ${ }^{48}$.

The Committee's Presidents were: Marian Zdziechowski (1922-5 X 1938) and Bronisław Krzyżanowski (1938-1939), Vice Presidents: Tadeusz Wróblewski (1922-3 VII 1925), Ludwik Abramowicz (1925-19 III 1939), treasurers: Jan Piłsudski (1922-1928), Wacław Wejtko (1929-1935), Romuald Węckowicz (1936-1939), members: Zygmunt Jundziłł, Stanisław Kościałkowski, Helena Romer-Ochenkowska, Witold Sławiński, Antoni Kazimierz Romer, Ludwik Chomiński ${ }^{49}$.

After the Wróblewski State Library opening ceremony, which took place on June 22, $1935^{50}$, Stefan Burhardt, its director, proposed an idea to establish another organization supporting the library - the Society of Friends of the Eustachy and Emilia Wróblewski State Library. Therefore the Organisational Commission was established in autumn 1936, chaired by priest Franciszek Tyczkowski, a bibliophile. It aimed at developing the draft statute and making connections with people who could have become the founding members. The founding meeting took place on December 17, 1936, in the Wróblewski State Library building ${ }^{51}$. The Society's statute was approved on January 12, 1937, and enrolled in the register of societies and unions of the Vilnius Voivodeship Office, no 1922. The Society was located in the Wróblewski State Library in Vilnius, Zygmuntowska 2 str. $^{52}$

After acquiring a legal basis, on February 2, 1937, the Organisation Commission developed and disseminated an appeal to the public, presenting the Society's

47 LCVA, sign. F 285, ap. 1, b. 5, pp. 14-15, Sprawozdanie roczne nr 6 z działalności Biblioteki Państwowej im. Wróblewskich w Wilnie za $1931 \mathrm{r}$.

48 H. Ilgiewicz, Biblioteka Państwowa im. Eustachego i Emilii Wróblewskich w Wilnie (19121939) oraz towarzystwa ja popierające, Toruń 2015, pp. 35-39.

49 Ibidem, pp. 235-236.

50 [Charkiewicz Walerian] W.Ch., Otwarcie biblioteki E. i E. Wróblewskich, "Słowo" 23.06.1935, no 169 (4018), p. 5; Poświęcenie i otwarcie Biblioteki im. Wróblewskich, "Ateneum Wileńskie' 1935, vol.10, pp. 571-572.

51 LVCA, sign. F 285, ap. 1, b. 9, pp. 1-2, Protokół zebrania organizacyjnego założycieli Towarzystwa Przyjaciół Biblioteki Wróblewskich w Wilnie z dn. 17 grudnia 1936 r.

52 LCVA, sign. F 53, ap. 23, b. 1591, pp. 9-12, Statut Towarzystwa Przyjaciół Biblioteki im. Wróblewskich w Wilnie; LCVA, sign. F 285, ap. 1, b. 11, pp. 1-2, Sprawozdanie Komisji Organizacyjnej Towarzystwa Przyjaciół Biblioteki im. Wróblewskich w Wilnie za okres działalności od 21 XI 1936 do 22 II 1937. 
aims and tasks, and appealing for support of its activity. The first general meeting of the Society's members took place on February 23, 1937, in the Wróblewski State Library. The report of the Organisational Commission was presented, the Management Board and the Review Commission elected, as well as the members of the Court of Honor. Concluding, priest Piotr Śledziewski Ph.D. gave a speech Trzy figury świętych na tympanonie Bazyliki św. Stanistawa w Wilnie (Three figures of saints on the tympanum of Saint Stanislaus Basilica in Vilnius), which which met with great interest of the listeners ${ }^{53}$.

New members of the Board at the first meeting on March 1, 1937, elected the President F. Tyczkowski, Vice President Tadeusz Dąbrowski, a judge, treasurer Anna Przyłuska, and secretary Helena Drège. Kazimierz Burczak, Teodor Bujnicki and Irena Hołownina became members of the Board. According to the Statue, it was also joined by S. Burhardt, representative of the Wróblewski State Library, and L. Abramowicz, representative of the Committee of the Society of Friends of the Eustachy and Emilia Wróblewski State Library. T. Bunicki represented the Scientific and Research Institute of Eastern Europe $^{54}$ (Instytut Naukowo-Badawczy Europy Wschodniej). This status had been maintained until the end of the society's activity, with one change - after the death of L. Abramowicz (on March 9, 1939) a new representative of the Committee had not been elected, and the Board had worked until the outbreak of World War II in a state of partial completion ${ }^{55}$. The founders became first members of the Society of Friends of the Eustachy and Emilia Wróblewski State Library, 44 persons in total ${ }^{56}$. Thanks to the Board's efforts, their number grew significantly in the following years. There were 130 members at the end of 1937, 135 in 1938, 126 in 1939. The organization had 145 in general in the years $1936-1939^{57}$.

53 LCVA, sign. F 285, ap. 1, b. 9, pp. 4-5, Protokół pierwszego Walnego Zgromadzenia Towarzystwa Przyjaciół Biblioteki im. Wróblewskich w Wilnie z dnia 23 lutego 1937 r., odbytego w lokalu Biblioteki Państwowej im. Wróblewskich w Wilnie przy ul. Zygmuntowskiej 2 o godz. 7 wieczorem; LCVA, sign. F 285, ap. 1, b. 11, pp. 1-2, Sprawozdanie Komisji Organizacyjnej Towarzystwa Przyjaciół Biblioteki im. Wróblewskich w Wilnie za okres działalności od 21 XI 1936 do 22 II 1937.

54 LCVA, sign. F 285, ap. 1, b. 11, pp. 3-6, Sprawozdanie z działalności Zarządu Towarzystwa Przyjaciół Biblioteki im. Wróblewskich w Wilnie za okres czasu od listopada 1936 r. do 31 stycznia $1937 \mathrm{r}$.

55 LCVA, sign. F 53, ap. 23, b. 1591, p. 29, Pismo Towarzystwa Przyjaciół Biblioteki im. Wróblewskich do Pana Starosty Grodzkiego w Wilnie, Wilno, dn. 12 marca 1937 r.; LMAVB, RS, sign. F 75-21, pp. 80-82, Pismo Towarzystwa Przyjaciół Biblioteki im. Wróblewskich do Starostwa Grodzkiego w Wilnie, Wilno, dn. 13 maja 1939 r.

56 LCVA, sign. F 285, ap. 1, b. 9, p. 3, Lista członków założycieli Towarzystwa Przyjaciół Biblioteki im. Wróblewskich w Wilnie.

57 LMAVB, RS, sign. F 75-21, pp. 118-120, Lista członków Towarzystwa Przyjaciół Biblioteki im. Wróblewskich w Wilnie 1938 r.; LMAVB, RS, sign. F 75-15/6, pp. 333-385, Deklaracje członkowskie [Towarzystwo Przyjaciół Biblioteki im. Wróblewskich w Wilnie]; LCVA, sign. F 285, ap. 1, b. 11, pp. 3-6, Sprawozdanie z działalności Zarządu Towarzystwa Przyjaciół Biblioteki 
The Society's goal, as declared in its statute, was to support the Library in the realisation of its scientific plans, obtaining funds and development. The territory of Poland was its area of activity, with particular emphasis on four NorthEast voivodeships: Vilnius, Nowogród, Białystok, and Polesie ${ }^{58}$.

The Society's effectiveness depended mostly on the funds. Its income amounted to 2556 PLN in 1937, partially from the donations of the Bank of Poland (500 PLN), the State Agricultural Bank in Warsaw (600 PLN), the Christian Agricultural Bank at Antokol in Vilnius (18 PLN), membership fees (1157 PLN) and other sources. Expenditures amounted to 976 PLN in 1937. There was 1580 PLN at the Society bank account in the Christian Agricultural Bank at Antokol in Vilnius on January 1, 1938 ${ }^{59}$. In the year 1938 total income amounted to 2276 PLN, and expenditures - 706 PLN, with the sum of 3150 PLN on the account on January 1, 1939, and 2636 PLN on September $1,1939^{60}$.

Donations were spent on remuneration for the trainees and volunteers working in the Wróblewski State Library, and their social insurance. Current expenditures of the society (office, post, organization of events, etc.) were covered from membership fees and money gathered during events ${ }^{61}$.

Moreover, the members donated books, manuscripts, objects of arts and museum objects to the library, which made a permanent deposit of the Society

im. Wróblewskich w Wilnie za okres czasu od listopada 1936 r. do 31 stycznia 1937 r.; LMAVB, sign. RS, F 75-21, pp. 80-82, Pismo Towarzystwa Przyjaciół Biblioteki im. Wróblewskich do Starostwa Grodzkiego w Wilnie, Wilno, dn. 13 maja 1939 r.

58 Statut..., § 2, 3 .

59 LCVA, sign. F 285, ap. 1, b. 14, Księga kasowa Towarzystwa Przyjaciół Biblioteki im. Wróblewskich; LCVA, sign. F 285, ap. 1, b. 11, p. 4, Sprawozdanie z działalności Zarządu Towarzystwa Przyjaciół Biblioteki im. Wróblewskich w Wilnie za okres czasu od listopada 1936 r. do 31 grudnia $1937 \mathrm{r}$.

60 LCVA, sign. F 285, ap. 1, b. 12, p. 8, Protokół 8-go posiedzenia Zarządu Towarzystwa Przyjaciół Biblioteki im. Wróblewskich w Wilnie z dn. 21 października 1938 r.; LCVA, sign. F 285, ap. 1, b. 12, p. 9, Protokół 9-go posiedzenia Zarządu Towarzystwa Przyjaciół Biblioteki im. Wróblewskich w Wilnie z dn. 27 lutego 1939 r.

${ }_{61}$ LCVA, sign. F 285, ap. 1, b. 14, Księga kasowa Towarzystwa Przyjaciół Biblioteki im. Wróblewskich; LCVA, sign. F 285, ap. 1, b. 10, pp. 3, 8, Sprawozdania kasowe Towarzystwa Przyjaciół Biblioteki im. Wróblewskich w Wilnie; LMAVB, RS, sign. F 75-15/6, p. 331, Do Prezydium Banku Gospodarstwa Krajowego [Prośba Towarzystwa Przyjaciół Biblioteki im. Wróblewskich w Wilnie o przyznanie zasiłku na wsparcie praktykantów], Wilno, dn. 14 stycznia 1938 r.; LMAVB, RS, sign. F 75-15/6, p. 322, Bank Gospodarstwa Krajowego Sekretarz Generalny do Towarzystwa Przyjaciół Biblioteki im. Wróblewskich w Wilnie [Zawiadomienie o przyznaniu subwencji w kwocie 500 zł.], Warszawa, dn. 28 marca 1938 r.; LMAVB, RS, sign. F 75-15/8, p. 470, Do Dyrekcji Wileńskiego Banku Ziemskiego [Podziękowanie Zarządu Towarzystwa Przyjaciół Biblioteki im. Wróblewskich za przyznanie zapomogi na cele towarzystwa w sumie $50 \mathrm{zł}$ ], Wilno, dn. 18 sierpnia 1939 r.; LMAVB, RS, sign. F 75-15/8, p. 477, Do Sekretariatu Banku Polskiego w Warszawie [Podziękowanie Zarządu Towarzystwa Przyjaciół Biblioteki im. Wróblewskich za przyznanie subwencji w wysokości 500 zł], Wilno, dn. 6 marca 1939 r. 
of Friends of the Wróblewski State Library ${ }^{62}$. This deposit consisted of approximately 3 thousand volumes of books and magazines on December 15, 1939 , mostly works related to the history and culture of Vilnius and the Vilnius Region $^{63}$.

Events were an important element of the Society activity. They were attended by the members, representatives of other organizations, the school youth and all the Vilnius inhabitants interested in science and culture. The evening of regional song and poetry was organized on May 6, 1937, the Wróblewski State Library premises, and funds from tickets sale were spent on the Library's needs ${ }^{64}$. The lecture took place on May 28, 1938, of priest Piotr Śledziewski, Ph.D., an excellent expert in the Vilnius religious art, who spoke about Myśl św. Augustyna w architekturze, rzeźbach $i$ malowidłach kościoła św. Piotra i Pawła $w$ Wilnie ${ }^{65}$ (St Augustine's thought in architecture, sculptures and paintings in the ss. Peter and Paul church in Vilnius).

Poets and writers related to Vilnius and the Vilnius Region were also remembered. The evening celebration of the $50^{\text {th }}$ anniversary of the death of Józef Ignacy Kraszewski (1812-1887) was organized on June 11, 1937, in the Library, where Tadeusz Turkowski, the Society member, gave the lecture Kraszewski a Vilnius ${ }^{66}$ (Kraszewski and Vilnius). The exhibition concerning this writer was also a part of this celebration, presenting 88 objects from the collections of the Wróblewski State Library and the Library of the Society of Friends of Science in Vilnius ${ }^{67}$.

62 LCVA, sign. F 285, ap. 1, b. 11, pp. 4-6, Sprawozdanie z działalności Zarządu Towarzystwa Przyjaciół Biblioteki im. Wróblewskich w Wilnie za okres czasu od listopada 1936 r. do 31 grudnia 1937 r.; LMAVB, RS, sign. F 75-138, pp. 10, 13-15, 29-30, 40-44, Listy darów (Biblioteka im. Wróblewskich).

63 LMAVB, RS, sign. F 75-242, p. 3, Pranešimas apie Valstybine Vrublevskių vardo Biblioteką Vilniuje, Wilno, 1939 m. gruodžio mèn. $15 \mathrm{~d}$.

${ }^{64}$ LCVA, sign. F 53, ap. 23, b. 1591, pp. 18-19, Wieczór pieśni i poezji regionalnej. Zaproszenie i program; LCVA, sign. F 285, ap. 1, b. 12, p. 2, Protokół 2-go posiedzenia Zarządu Towarzystwa Przyjaciół Biblioteki im. Wróblewskich w Wilnie z dn. 6 kwietnia 1937 r.

65 LCVA, sign. F 285, ap. 1, b. 13, p. 8, Ogłoszenia i zaproszenia Towarzystwa Przyjaciół Biblioteki im. Wróblewskich na wieczory i zebrania; LCVA, sign. F 285, ap. 1, b. 11, p. 4, Sprawozdanie z działalności Zarządu Towarzystwa Przyjaciół Biblioteki im. Wróblewskich w Wilnie za okres czasu od listopada 1936 r. do 31 grudnia 1937 r.

66 LCVA, sign. F 285, ap. 1, b. 12, p. 2, Protokół 2-go posiedzenia Zarządu Towarzystwa Przyjaciół Biblioteki im. Wróblewskich w Wilnie z dn. 6 kwietnia 1937 r.; LCVA, sign. F 285, ap. 1, b. 13, p. 8, Ogłoszenia i zaproszenia Towarzystwa Przyjaciół Biblioteki im. Wróblewskich na wieczory i zebrania.

67 LMAVB, RS, sign. F 75-144, pp. 5-8, Materiał bibliograficzny, biograficzny oraz ikonograficzny do Józefa Ignacego Kraszewskiego z okresu jubileuszu 50-lecia pracy 1879 r. oraz śmierci 1887 r. znajdujący się na wystawie ku Jego czci, urządzonej w dn. 11-16 czerwca 1937 r. w Bibliotece Państwowej im. Wróblewskich w Wilnie. 
The evening celebration of the poet Władysław Syrokomla, on the $75^{\text {th }}$ anniversary of his death was organized on November 26, 1937. Speeches were given by M. Zdziechowski - Syrokomla - poeta naszej ziemi (Syrokomla - the poet of our land) and T. Turkowski - Syrokomla w życiu umystowym Wilna (Syrokomla in the Vilnius intellectual life). There was also an exhibition organized by the librarians and the Society members ${ }^{68}$.

The $75^{\text {th }}$ anniversary of the January Uprising outbreak was celebrated in 1938 in Vilnius. The Society organised a celebration evening at the Library on this occasion in the evening on January 22. Ryszard Mienicki, a historian and archivist, discussed the January Uprising at the territory of the former Great Duchy of Lithuania, and the actors from the Municipal Theatre declaimed poetry of that time ${ }^{69}$. A lecture meeting of the Society took place on November 26, where Jerzy Orda Ph.D. spoke about Zagadnienie stylu $w$ plastyce (The problem of style in the art), and presented slides. The lecture was followed by a vivid discussion ${ }^{70}$.

Evenings of songs and poetry, lectures, anniversaries, and similar events organized by the Society attracted Vilnius intelligentsia and students to the Library, therefore reviving cultural life in the interwar Vilnius. It was also an occasion to know better the Library, and for its managers and friends to recall the library' needs and expected social support.

The outbreak of World War II and the following occupations influenced tragically the fate of the aforementioned societies, and the libraries they supported. The societies were closed ${ }^{71}$, and libraries transferred to the Lithuanian institutions. The University Library, when the Lithuanian authorities closed the Stefan Batory University in December 1939, was transferred (just as the whole USB property) to the Lithuanian University

68 LMAVB, RS, sign. F 75-21, pp. 17-18, Wieczór ku czci Syrokomli, zorganizowany przez Towarzystwo Przyjaciół Biblioteki im. Wróblewskich; LCVA, sign. F 285, ap. 1, b. 13, p. 6, Ogłoszenia i zaproszenia Towarzystwa Przyjaciół Biblioteki im. Wróblewskich na wieczory i zebrania.

69 LCVA, sign. F 285, ap. 1, b. 13, p. 5, Ogłoszenia i zaproszenia Towarzystwa Przyjaciół Biblioteki im. Wróblewskich na wieczory i zebrania; LMAVB, RS, sign. F 75-15/8, pp. 446-467, Towarzystwo Przyjaciół Biblioteki im. Wróblewskich w Wilnie [Sprawozdanie z działalności za lata 1937-1939], Vilnius 1939.

70 LCVA, sign. F 285, ap. 1, b. 13, p. 3, Ogłoszenia i zaproszenia Towarzystwa Przyjaciół Biblioteki im. Wróblewskich na wieczory i zebrania.

71 LCVA, sign. F 402, ap. 11, b. 349, p. 87, Vidaus reikalų ministro A. Guzevičiaus 1940 $\mathrm{m}$. birželio $27 \mathrm{~d}$. nutarimas sustabdyti visų draugijų ir jų padalinių, veikusių ligi $1940 \mathrm{~m}$. birželio 20 d. veikimą, Kaunas, 1940 m. birželio 27 d.; LCVA, sign. F 402, ap. 11, b. 349, pp. 108-111, Nebeveikiančių draugijų turto paskirčiai nustatyti komisijos (Pagrindas: VR ministro1940 m. įsakas Nr. 88, § 1) protokolo Nr. 9, 1940 m. rugpjūčio 21 d. nuorašas. 
of Vilnius ${ }^{72}$. In autumn 1939, when Vilnius and the Vilnius Region were joined to the Republic of Lithuania, the Wróblewski State Library came under management of the Ministry of Education of Lithuania, and next, after establishment of the Soviet authorities in Lithuania, to the Institute of Lithuanistics, moved from Kowno to Vilnius (on September 1, 1940) and renamed as the Central Library of the Institute of Lithuanistics ${ }^{73}$. A special commission revised its collections and left approximately $42 \%$ of prints for the readers' use. The rest become secured and unavailable for the readers. A part of publications (approx. 10\%) were considered as a lecture hostile towards "the Constitution of the Lithuanian Soviet Socialist Republic and the settled social system" and withdrown from circulation, which means they were destroyed ${ }^{74}$. The former Wróblewski State Library changed its name and the owner once again at the beginning of 1941 . On January 16, 1941, the Institute of Lithuanistics was converted into the Academy of Sciences of the Lithuanian Soviet Socialist Republic, and also took over the library renamed as the Central Library of the Academy of Sciences of LSSR. This library was closed in March 1943, on the order of German occupation authorities. After Vilnius liberation from the German occupation and return of the Soviet authority, the library renewed its activity as the Central Library of the Academy of Sciences of the LSSR. It has been working as the Library of the Lithuanian Academy of Sciences since Lithuania regained independence in 1991. The Wróblewski name was returned to the library in 2009 (Lietuvos mokslu akademijos Vrublevskiu biblioteka $)^{75}$.

The Tomasz Zan Library, which played an important role in the interwar period, did not survive the World War II. The library building was burnt in summer 1944, during the German withdrawal from Vilnius, and the saved part of the collection was divided among other libraries ${ }^{76}$. However, the Vilnius inhabitants retained their memory. The Vilnius municipality gave Tomasz Zan name to the branch at St Stefan str. (Lit. Šv. Stepono) of the Central Library

\footnotetext{
72 Likwidacja Uniwersytetu Stefana Batorego przez władze litewskie w grudniu 1939 roku: Dokumenty i materiały, collected and introduction by P. Łossowski, Warszawa 1991; Vilniaus universiteto istorija 1579-1994, Wilno 1994, pp. 243-246.

73 Lietuvos mokslu akademijos Vrublevskiu biblioteka1912-2012, Wilno 2011, p. 18; Biblioteka im. Wróblewskich Litewskiej Akademii Nauk 1912-2012, Wilno 2011, p. 18.

74 LMAVB, RS, F 75-249, p. 68, Lituanistikos Instituto Bibliotekos Konservatorius Bibliotekos Vedejui [A. Ružancovo ataskaita], Wilno, 1940. XI. 6 d.

${ }_{75}$ Lietuvos mokslu akademijos Vrublevskiu..., pp. 19-36; Biblioteka im. E. i E. Wróblewskich, [in:] Encyklopedia Ziemi Wileńskiej. Vol. 6: Książka i prasa na Ziemi Wileńskiej, drukarnie, wydawnictwa, księgarnie, biblioteki, czasopisma XVI w. - 1945 r., compiled by M. Jackiewicz, Bydgoszcz 2008, pp. 59-60.

76 Biblioteki na wschodnich ziemiach II Rzeczypospolitej..., p. 610.
} 
of Vilnius in 1999. This facility is active among local inhabitants and focuses in particular on children and youth ${ }^{77}$.

Translated by Matgorzata Kisilowska

\section{References}

Archival sources

Lietuvos centrinis valstybès archyvas (Państwowe Archiwum Centralne Litwy, Eng. Luthianian Central State Archives, abbreviation: LCVA):

LCVA, sign. F 285, ap. 1, b. 12, p. 2, Protokół 2-go posiedzenia Zarządu Towarzystwa Przyjaciół Biblioteki im. Wróblewskich w Wilnie z dn. 6 kwietnia 1937 r.

LCVA, sign. F 285, ap. 1, b. 12, p. 8, Protokół 8-go posiedzenia Zarządu Towarzystwa Przyjaciół Biblioteki im. Wróblewskich w Wilnie z dn. 21 października 1938 r.

LCVA, sign. F 285, ap. 1, b. 12, p. 9, Protokół 9-go posiedzenia Zarządu Towarzystwa Przyjaciół Biblioteki im. Wróblewskich w Wilnie z dn. 27 lutego 1939 r.

LCVA, sign. F 285, ap. 1, b. 14, Księga kasowa Towarzystwa Przyjaciół Biblioteki im. Wróblewskich.

LCVA, sign. F 285, ap. 1, b. 5, pp. 14-15, Sprawozdanie roczne nr 6 z działalności Biblioteki Państwowej im. Wróblewskich w Wilnie za $1931 \mathrm{r}$.

LCVA, sign. F 285, ap. 1, b. 9, p. 3, Lista członków założycieli Towarzystwa Przyjaciół Biblioteki im. Wróblewskich w Wilnie.

LCVA, sign. F 285, ap. 1, b. 9, pp. 1-2, Protokół zebrania organizacyjnego założycieli Towarzystwa Przyjaciół Biblioteki Wróblewskich w Wilnie z dn. 17 grudnia 1936 r.

LCVA, sign. F 402, ap. 11, b. 349, pp. 108-111, Nebeveikiančių draugijų turto paskirčiai nustatyti komisijos (Pagrindas: VR ministro1940 m. įsakas Nr. 88, § 1) protokolo Nr. 9, 1940 m. rugpjūčio 21 d. nuorašas.

LCVA, sign. F 402, ap. 11, b. 349, p. 87, Vidaus reikalų ministro A. Guzevičiaus 1940 m. birželio 27 d. nutarimas sustabdyti visų draugijų ir jų padalinių, veikusių ligi 1940 m. birželio 20 d. veikimą, Kaunas, 1940 m. birželio 27 d.

LCVA, sign. F 53, ap. 23, b. 1591, pp. 18-19, Wieczór pieśni i poezji regionalnej. Zaproszenie i program.

LCVA, sign. F 53, ap. 23, b. 1591, p. 29, Pismo Towarzystwa Przyjaciół Biblioteki im. Wróblewskich do Pana Starosty Grodzkiego w Wilnie, Vilnius, dn. 12 marca 1937 r.

LCVA, sign. F 53, ap. 23, b. 2516, p. 11, Towarzystwo Przyjaciół Biblioteki Uniwersytetu Stefana Batorego w Wilnie do Pana Starosty Grodzkiego w Wilnie, Vilnius, dn. 1 XII.1932 r.

LCVA, sign. F 53, ap. 23, b. 2516, p. 18, Towarzystwo Przyjaciół Biblioteki Uniwersytetu Stefana Batorego w Wilnie do Pana Starosty Grodzkiego w Wilnie, Vilnius, 15.V.1931 r.

77 Biblioteka im. Tomasza Zana w Wilnie, w: Encyklopedia Ziemi Wileńskiej. Vol. 6 ..., p. 61. 
LCVA, sign. F 53, ap. 23, b. 2516, p. 3, Towarzystwo Przyjaciół Biblioteki Uniwersytetu Stefana Batorego w Wilnie do Pana Starosty Grodzkiego w Wilnie, 23 kwietnia $1936 \mathrm{r}$.

LCVA, sign. F 53, ap. 23, b. 2516, p. 4, Starostwo Grodzkie Wileńskie do Zarządu Towarzystwa Przyjaciół Biblioteki USB w Wilnie, Vilnius, 5.V.1931.

LCVA, sign. F 53, ap. 23, b. 2516, p. 5, Wileński Urząd Wojewódzki Wydział Bezpieczeństwa do Pana Starosty Grodzkiego w Wilnie, Vilnius, dn. 28.I.1931 r

LCVA, sign. F 53, ap. 23, b. 2516, p. 8, Protokół III posiedzenia Zarządu Przyjaciół Uniwersyteckiej Biblioteki Publicznej w Wilnie w dniu 19 kwietnia 1932 r.

LCVA, sign. F 53, ap. 23, b. 2516, p. 1, Arkusz ewidencyjny Towarzystwa Przyjaciół Biblioteki USB w Wilnie.

LCVA, sign. F 285, ap. 1, b. 13, pp. 3, 5, 6, 8, Ogłoszenia i zaproszenia Towarzystwa Przyjaciół Biblioteki im. Wróblewskich na wieczory i zebrania.

LCVA, sign. F 285, ap. 1, b. 11, pp. 1-2, Sprawozdanie Komisji Organizacyjnej Towarzystwa Przyjaciół Biblioteki im. Wróblewskich w Wilnie za okres działalności od 21 XI 1936 do 22 II 1937.

LCVA, sign. F 285, ap. 1, b. 11, pp. 3-6, Sprawozdanie z działalności Zarządu Towarzystwa

Przyjaciół Biblioteki im. Wróblewskich w Wilnie za okres czasu od listopada 1936 r. do 31 grudnia $1937 \mathrm{r}$.

LCVA, sign. F 285, ap. 1, b. 9, pp. 4-5, Protokół pierwszego Walnego Zgromadzenia Towarzystwa Przyjaciół Biblioteki im. Wróblewskich w Wilnie z dnia 23 lutego 1937 r., odbytego w lokalu Biblioteki Państwowej im. Wróblewskich w Wilnie przy ul. Zygmuntowskiej 2 o godz. 7 wieczorem.

LCVA, sign. F 53, ap. 23, b. 1591, pp. 9-12, Statut Towarzystwa Przyjaciół Biblioteki im. Wróblewskich w Wilnie.

LCVA, sign. F 285, ap. 1, b. 10, pp. 3, 8, Sprawozdania kasowe Towarzystwa Przyjaciół Biblioteki im. Wróblewskich w Wilnie.

Lietuvos mokslų akademijos Vrublevskių biblioteka, Rankraščių skyrius (Pol. Biblioteka im. Wróblewskich Litewskiej Akademii Nauk, Dział Rękopisów, Eng. The Wróbłewski Library of the Lithuanian Academy of Sciences, Department of Manuscripts, abbreviation: LMAVB, RS):

LMAVB, RS, F 75-249, p. 68, Lituanistikos Instituto Bibliotekos Konservatorius Bibliotekos Vedèjui [A. Ružancovo ataskaita], Vilnius, 1940. XI. 6 d.

LMAVB, RS, sign. F 75-21, pp. 17-18, Wieczór ku czci Syrokomli, zorganizowany przez Towarzystwo Przyjaciół Biblioteki im. Wróblewskich

LMAVB, RS, sign. F 75-21, pp. 118-120, Lista członków Towarzystwa Przyjaciół Biblioteki im. Wróblewskich w Wilnie $1938 \mathrm{r}$.

LMAVB, RS, sign. F 75-21, pp. 80-82, Pismo Towarzystwa Przyjaciół Biblioteki im. Wróblewskich do Starostwa Grodzkiego w Wilnie, Vilnius, dn. 13 maja 1939 r.

LMAVB, RS, sign. F 75-242, p. 3, Pranešimas apie Valstybine Vrublevskių vardo Biblioteką Vilniuje, Vilnius, 1939 m. gruodžio mèn. 15 d. 
LMAVB, RS, sign. F 75-711, pp. 51-56, Statut Towarzystwa Przyjaciół Biblioteki Uniwersytetu Stefana Batorego w Wilnie.

LMAVB, sign. RS, F 75-21, pp. 80-82, Pismo Towarzystwa Przyjaciół Biblioteki im. Wróblewskich do Starostwa Grodzkiego w Wilnie, Vilnius, dn. 13 maja 1939 r.

LMAVB, RS, sign. F 75-8, p. 46, Protokół nr 6 zebrania Komitetu Towarzystwa Pomocy Naukowej im Eustachego i Emilii Wróblewskich w dniu 12 czerwca 1930 r.

LMAVB, RS, sign. F 75-22/2, pp. 106-109, Umowa podpisana pomiędzy Stefanem Dembym, działającym w imieniu Ministerstwa Wyznań Religijnych i Oświecenia Publicznego na mocy zlecenia Ministra WR i OP Pana Stanisława Grabskiego a Komitetem Towarzystwa Pomocy Naukowej im. Eustachego i Emilii Wróblewskich, istniejącego na mocy Statutu, zatwierdzonego przez Delegata Rządu dla Ziemi Wileńskiej w dn. 19-ym sierpnia 1922 roku, Vilnius, dn. 1 lutego $1926 \mathrm{r}$.

LMAVB, RS, sign. F 75-144, pp. 5-8, Materiał bibliograficzny, biograficzny oraz ikonograficzny do Józefa Ignacego Kraszewskiego z okresu jubileuszu 50-lecia pracy 1879 r. oraz śmierci 1887 r. znajdujący się na wystawie ku Jego czci, urządzonej w dn. 11-16 czerwca 1937 r. w Bibliotece Państwowej im. Wróblewskich w Wilnie.

LMAVB, RS, sign. F 75-15/6, p. 322, Bank Gospodarstwa Krajowego Sekretarz Generalny do Towarzystwa Przyjaciół Biblioteki im. Wróblewskich w Wilnie [Zawiadomienie o przyznaniu subwencji w kwocie 500 zł.], Warszawa, dn. 28 marca 1938 r.

LMAVB, RS, sign. F 75-15/6, p. 331, Do Prezydium Banku Gospodarstwa Krajowego [Prośba Towarzystwa Przyjaciół Biblioteki im. Wróblewskich w Wilnie o przyznanie zasiłku na wsparcie praktykantów], Vilnius, dn. 14 stycznia $1938 \mathrm{r}$.

LMAVB, RS, sign. F 75-15/6, pp. 333-385, Deklaracje członkowskie [Towarzystwo Przyjaciół Biblioteki im. Wróblewskich w Wilnie].

LMAVB, RS, sign. F 75-15/8, pp. 446-467, Towarzystwo Przyjaciół Biblioteki im. Wróblewskich w Wilnie [Sprawozdanie z działalności za lata 1937-1939], Vilnius 1939.

LMAVB, RS, sign. F 75-15/8, p. 470, Do Dyrekcji Wileńskiego Banku Ziemskiego [Podziękowanie Zarządu Towarzystwa Przyjaciół Biblioteki im. Wróblewskich za przyznanie zapomogi na cele towarzystwa w sumie 50 zł], Vilnius, dn. 18 sierpnia $1939 \mathrm{r}$.

LMAVB, RS, sign. F 75-15/8, p. 477, Do Sekretariatu Banku Polskiego w Warszawie [Podziękowanie Zarządu Towarzystwa Przyjaciół Biblioteki im. Wróblewskich za przyznanie subwencji w wysokości 500 zł], Vilnius, dn. 6 marca 1939 r.

LMAVB, RS, sign. F 75-138, pp. 10, 13-15, 29-30, 40-44, Listy darów (Biblioteka im. Wróblewskich).

LMAVB, RS, sign. F 75-11/4, pp. 282-288, Sprawozdanie z działalności Biblioteki Państwowej im. Wróblewskich w Wilnie za 1930 r.

Vilniaus universiteto biblioteka, Rankraščių skyrius, (Biblioteka Uniwersytetu Wileńskiego, Dział Rękopisów, abbreviation VUB, RS): 
VUB, RS, sign. F 47-716, p. 13, Protokół III posiedzenia Zarządu Towarzystwa Przyjaciół Biblioteki Uniwersytetu Stefana Batorego w Wilnie dn. 9 lutego 1925 r.

VUB, RS, sign. F 47-712/1, p. 12, Deklaracja [Witolda Rudzińskiego] do Zarządu

Towarzystwa Przyjaciół Biblioteki Uniwersyteckiej w Wilnie, dn. 16 lipca 1936 r.

VUB, RS, sign. F 47-712/1, p. 13, Deklaracja [Sergiusza Arsenjewa] do Zarządu

Towarzystwa Przyjaciół Biblioteki Uniwersyteckiej w Wilnie, dn. 15. III.1936 r.

VUB, RS, sign. F 47-712/1, p. 15, Deklaracja [Stanisława Lisowskiego] do Zarządu

Towarzystwa Przyjaciół Biblioteki Uniwersyteckiej w Wilnie, 15 marca 1938 r.

VUB, RS, sign. F 47-712/1, p. 16, Deklaracja [Henryka Rzędowskiego] do Zarządu

Towarzystwa Przyjaciół Biblioteki Uniwersyteckiej w Wilnie, 1 marca 1938 r.

VUB, RS, sign. F 47-712/1, p. 17, Deklaracja [Henryka Teitelbauma] do Zarządu

Towarzystwa Przyjaciół Biblioteki Uniwersyteckiej w Wilnie, 7 kwietnia 1938 r.

VUB, RS, sign. F 47-712/1, p. 18, Deklaracja [Wacławy Walickiej] do Zarządu

Towarzystwa Przyjaciół Biblioteki Uniwersyteckiej w Wilnie, 15 marca 1938 r.

VUB, RS, sign. F 47-712/1, p. 19, Deklaracja [Napoleona Baniewicza] do Zarządu

Towarzystwa Przyjaciół Biblioteki Uniwersyteckiej w Wilnie.

VUB, RS, sign. F 47-712/1, p. 27, Sprawozdanie Zarządu Towarzystwa Przyjaciół

Biblioteki Uniwersyteckiej w Wilnie za czas od 27.V.1935 do 26.VI. 1936.

VUB, RS, sign. F 47-712/1, Spis członków Towarzystwa Przyjaciół Biblioteki Uniwersyteckiej w Wilnie, 1936.

VUB, RS, sign. F 47-716, p. 10, Protokół I posiedzenia Zarządu dn. 7 lipca 1924 r.

VUB, RS, sign. F 47-716, p. 11, Protokół II zwyczajnego posiedzenia Zarządu Towarzystwa

Przyjaciół Biblioteki Uniwersytetu Stefana Batorego w dniu 11.VIII.1924 r.

VUB, RS, sign. F 47-716, p. 13, Protokół III posiedzenia Zarządu Towarzystwa Przyjaciół

Biblioteki Uniwersytetu Stefana Batorego w Wilnie dn. 9 lutego1925 r.

VUB, RS, sign. F 47-716, pp. 17-23, Protokół Walnego Zebrania Towarzystwa Przyjaciół

Biblioteki Publicznej Uniwersyteckiej, odbytego w lokalu Biblioteki Publicznej Uniwersyteckiej 6. III. $1926 \mathrm{r}$.

VUB, RS, sign. F 47-716, pp. 33-34, Protokół walnego zebrania członków Towarzystwa

Przyjaciół Uniwersyteckiej Biblioteki Publicznej w Wilnie, odbytego dnia 11 maja

1931 r. w gmachu Uniwersyteckiej Biblioteki Publicznej.

VUB, RS, sign. F 47-716, pp. 36-37, Protokół walnego zebrania członków Towarzystwa

Przyjaciół Uniwersyteckiej Biblioteki Publicznej w Wilnie, odbytego dnia 27 maja

1935 r. w gmachu Uniwersyteckiej Biblioteki Publicznej.

VUB, RS, sign. F 47-716, p. 37, Protokół V (XVI) posiedzenia Zarządu Towarzystwa

Przyjaciół Biblioteki Uniwersyteckiej w Wilnie w dn. 27 maja 1935 r.

VUB, RS, sign. F 47-716, pp. 37-38, ProtokółVI (XVIII) posiedzenia Zarządu Towarzystwa

Przyjaciół Biblioteki Publicznej i USB w Wilnie, odbytego w dn. 18.V.1936 r.

w gmachu Biblioteki Uniwersyteckiej o godz. 18.30.

VUB, RS, sign. F 47-716, wklejka na drugiej stronie okładki Księgi protokołów, Skład

Zarządu Towarzystwa Przyjaciół Biblioteki Publicznej Uniwersyteckiej. 
VUB, RS, sign. F 47-717/1, pp. 13-18, Książka rachunkowa Towarzystwa Przyjaciół Biblioteki Publicznej i USB w Wilnie.

VUB, RS, sign. F 47-922/1, pp. 1-3, Statut Towarzystwa Przyjaciół Biblioteki Uniwersytetu Stefana Batorego w Wilnie.

Printed sources

Likwidacja Uniwersytetu Stefana Batorego przez władze litewskie w grudniu 1939 roku: Dokumenty $i$ materiaty, collected and introduction by P. Łossowski, Warszawa 1991.

Statut Towarzystwa Pomocy w Samoksztatceniu imienia Tomasza Zana, Wilno 1932.

Articles

[Charkiewicz Walerian] W.Ch., Biblioteka im. Tomasza Zana w Wilnie, "Słowo" 25.11.1937, no 327 (4891), p. 5.

[Charkiewicz Walerian] W.Ch., Otwarcie biblioteki E. i E. Wróblewskich, "Słowo", 23.06.1935, no 169 (4018), p. 5.

Biblioteka Uniwersytecka w Wilnie w roku 1935/36, “Kurier Wileński” 23.10.1936, no 291 (3894), p. 7.

Czytelnia "Samokształcenie” Koła Bibliotecznego im. Tomasza Zana PMSz, ul. Św. Anny 7, "Gazeta Wileńska” 24.12.1920, no 52, p. 7.

Działalność Koła Bibliotecznego im. Tomasza Zana, "Oświata Pozaszkolna” 1922, vol. 2, no 6, pp. 407-408.

K.B., Towarzystwo Przyjaciół Biblioteki Uniwersyteckiej w Wilnie, "Słowo" 15.04.1924, no 87 (504), p. 2.

Kronika: Zarząd Towarzystwa Przyjaciót Uniwersyteckiej Biblioteki Publicznej w Wilnie, "Słowo" 25.04.1931, no 94 (2602), p. 3.

M.W., Otwarcie Biblioteki im. Tomasza Zana, "Kurier Wileński" 02.11.1936, no 301 (3904), p. 2.

Nabożeństwo za duszę ś. p. Tomasza Zana, “Gazeta Wileńska” 19.12.1920, no 48, p. 3.

Nowa placówka, "Gazeta Wileńska” 28.12.1920, no 53, p. 3.

Odezwa Polskiej Macierzy Szkolnej, "Gazeta Wileńska” 14.11.1920, no 19, p. 4.

Otwarcie czytelni "Samokształcenie”, "Gazeta Wileńska” 19.12.1920, no 48, p. 3.

Parczewski A., O pomoc dla Biblioteki Uniwersytetu w Wilnie, "Słowo” 3.04.1924, no 77 (494), p. 2.

Podziękowanie [Zarządu Koła Bibliotecznego im. Tomasza Zana Polskiej Macierzy Szkolnej], "Gazeta Wileńska” 24.12.1920, no 52, p. 7.

Polska Macierz Szkolna do społeczeństwa polskiego, "Gazeta Wileńska” 23.12.1920, no 51, p. 3.

Poświęcenie i otwarcie Biblioteki im. Wróblewskich, “Ateneum Wileńskie” 1935, vol. 10, pp. 571-572.

Radlińska H., Biblioteka i czytelnia im. Tomasza Zana w Wilnie, "Oświata i Wychowanie" 1930, vol. 2, no 8, pp. 789-791. 
Romer H. [Romer-Ochenkowska Helena], Biblioteka i czytelnia im. T. Zana w nowym lokalu, "Kurier Wileński" 25.10.1936, no 293 (3896), p. 12.

Rygiel S., Vilnius swej bibliotece, "Słowo" 19/20. 04.1924, no 90 (507), p. 3.

Towarzystwo Przyjaciót Biblioteki Publicznej i Uniwersyteckiej w Wilnie (Uniwersytecka 5, Biblioteka), "Nauka Polska" 1927, vol. 7, p. 424.

Towarzystwo Przyjaciół Biblioteki Uniwersytetu Stefana Batorego w Wilnie, "Nauka Polska" 1925, vol. 5, p. 428; 1927, vol. 6, p. 364, vol. 7, p. 424.

Towarzystwo Przyjaciót Uniwersyteckiej Biblioteki Publicznej w Wilnie, "Kurier Wileński”, 25.04.1931, no 94 (2036), p. 3.

T-wo Przyjaciół Uniw. Biblioteki Publicznej w Wilnie, "Słowo", 25.04.1931, no 94 (2602), p. 3 .

Literature

Biblioteka im. E. i E. Wróblewskich, [in:] Encyklopedia Ziemi Wileńskiej. Vol. 6: Książa i prasa na Ziemi Wileńskiej, drukarnie, wydawnictwa, księgarnie, biblioteki, czasopisma XVI w. - 1945 r., compiled by M. Jackiewicz, Bydgoszcz 2008, pp. 59-60. Biblioteka im. Wróblewskich Litewskiej Akademii Nauk 1912-2012, Vilnius 2011.

Biblioteki na wschodnich ziemiach II Rzeczypospolitej: Informator, ed. by B. Bieńkowska, compiled by U. Paszkiewicz et al., Poznań 1998.

Borowski Jan, ur. 1890, zm. 1966; architekt, pedagog, [in:] Encyklopedia Ziemi Wileńskiej: Architektura, dzieła i twórcy od XVI w. do 1945 r., compiled by M. Jackiewicz, Bydgoszcz 2006, pp. 16-17.

Ilgiewicz H., Biblioteka Państwowa im. Eustachego i Emilii Wróblewskich w Wilnie (1912-1939) oraz towarzystwa ja popierajace, Toruń 2015.

Lietuvos mokslu akademijos Vrublevskiu biblioteka1912-2012, Vilnius 2011.

Ruszczycówna L., Biblioteka im. Tomasza Zana, w: Biblioteki wileńskie, ed. by A. Łysakowski, Vilnius 1932, pp. 165-174.

Vilniaus universiteto istorija 1579-1994, Vilnius 1994. 